\title{
BMJ
}

\section{Lung cancer deaths from indoor radon and the cost effectiveness and potential of policies to reduce them}

\author{
Alastair Gray, professor of health economics, ${ }^{1}$ Simon Read, analyst and programmer, ${ }^{2}$ Paul McGale, \\ statistician, ${ }^{2}$ Sarah Darby, professor of medical statistics ${ }^{2}$
}

\begin{abstract}
${ }^{1}$ Health Economics Research Centre, Department of Public Health, University of Oxford, Oxford OX3 7LF

${ }^{2}$ Clinical Trial Service Unit and Epidemiological Studies Unit, University of Oxford

Correspondence to: A Gray alastair.gray@dphpc.ox.ac.uk

Cite this as: BMJ 2009;338:a3110 doi:10.1136/bmi.a3110
\end{abstract}

\author{
ABSTRACT \\ Objective To determine the number of deaths from lung \\ cancer related to radon in the home and to explore the cost \\ effectiveness of alternative policies to control indoor \\ radon and their potential to reduce lung cancer mortality. \\ Design Cost effectiveness analysis. \\ Setting United Kingdom.
}

Data sources Epidemiological data on risks from indoor radon and from smoking, vital statistics on deaths from lung cancer, survey information on effectiveness and costs of radon prevention and remediation.

Main outcome measures Estimated number of deaths from lung cancer related to indoor radon, lifetime risks of death from lung cancer before and after various potential interventions to control radon, the cost per quality adjusted life year (QALY) gained from different policies for control of radon, and the potential of those policies to reduce lung cancer mortality.

Results The mean radon concentration in UK homes is 21 becquerels per cubic metre $\left(\mathrm{Bq} / \mathrm{m}^{3}\right)$. Each year around 1100 deaths from lung cancer $(3.3 \%$ of all deaths from lung cancer) are related to radon in the home. Over $85 \%$ of these arise from radon concentrations below $100 \mathrm{~Bq} / \mathrm{m}^{3}$ and most are caused jointly by radon and active smoking. Current policy requiring basic measures to prevent radon in new homes in selected areas is highly cost effective, and such measures would remain cost effective if extended to the entire UK, with a cost per QALY gained of $£ 11400$ ( $€ 12$ 200; \$16 913). Current policy identifying and remediating existing homes with high radon levels is, however, neither cost effective (cost per QALY gained $£ 36800$ ) nor effective in reducing lung cancer mortality. Conclusions Policies requiring basic preventive measures against radon in all new homes throughout the UK would be cost effective and could complement existing policies to reduce smoking. Policies involving remedial work on existing homes with high radon levels cannot prevent most radon related deaths, as these are caused by moderate exposure in many homes. These conclusions are likely to apply to most developed countries, many with higher mean radon concentrations than the UK.

\section{INTRODUCTION}

Lung cancer is the commonest fatal cancer in many countries; in the United Kingdom in 2006 it accounted for $22 \%$ of deaths from cancer. ${ }^{1}$ Most lung cancers are caused by cigarette smoking, but another recognised lung carcinogen ${ }^{2}$ is the chemically inert gas radon-222 (half-life four days), a ubiquitous natural air pollutant arising from radioactive decay of the uranium-238 present throughout the earth's crust. Outdoor radon concentrations are usually low, but indoors they are higher, especially in houses and other small buildings, and in most countries radon is the largest source of exposure to natural ionising radiation. ${ }^{2}$

If inhaled, solid short lived radon progeny may deposit on the bronchial epithelium exposing sensitive cells to $\alpha$ irradiation. Radiobiological evidence suggests that cells exposed to even a single $\alpha$ particle become appreciably damaged. Therefore, at low doses the risk of cancer is proportional to the number of cells exposed, and the dose-response relation is likely to be linear. ${ }^{3}$ For most people the bronchial dose of radiation is determined principally by the concentration of radon in the home. Studies of radon related lung cancer have quantified the risk in terms of radon concentration rather than radiation dose because concentrations can be measured directly. For the same reason policies to control radon are usually formulated in terms of radon concentration.

The risk from indoor radon used to be estimated indirectly by extrapolation from risks seen in miners exposed to radon. Such extrapolations had limitations, however, as the miners were exposed under different conditions, usually at much higher concentrations, and little information was available on their smoking histories. Recently, direct evidence has become available on the risk of lung cancer from indoor radon in people with well documented smoking histories. ${ }^{4-6}$ This clearly confirms a material risk and it enables the number of deaths from radon related lung cancer to be estimated with greater confidence.

Considerable reductions in future radon concentrations in new buildings can usually be obtained at low cost - for example, by means of a sealed membrane at ground level, whereas in existing buildings substantial reductions can usually be achieved at moderate cost. ${ }^{7}$ It is appropriate therefore to consider new buildings and existing buildings separately when assessing the cost effectiveness of radon control. Many countries already 
have policies to control radon. ${ }^{8}$ These usually focus on the small proportion of buildings where concentrations are above a specified value, typically known as the "action level" or "reference level." In the UK the action level for homes is currently 200 becquerels per cubic metre $\left(\mathrm{Bq} / \mathrm{m}^{3}\right)$ and current policy is mainly concerned with identifying existing homes with radon measurements above this level, although in areas with high radon levels basic preventive measures are also required for all new homes (table 1).

Previous economic evaluations of indoor radon ${ }^{9-12}$ have not made use of the recent direct evidence on the risk of lung cancer ${ }^{56}$ and have not given appropriate emphasis to protection in new buildings. Nor have they used the cost effectiveness methods now widely recommended for evaluating health interventions. ${ }^{13-15}$

We determined the number of deaths from lung cancer related to radon in the home and explored the cost effectiveness of various policies to control indoor radon and their potential to reduce deaths from lung cancer in the UK. The methods used are applicable to other countries, many of which have higher radon concentrations than the UK.

\section{METHODS}

\section{Number of deaths from radon related lung cancer}

We obtained the distribution of measured radon concentrations in UK homes from a nationwide representative survey.$^{16}$ Measured radon varies from year to year, and we estimated the magnitude of this variability from studies where measurements were made in the same home in several different years. ${ }^{5-18}$ We obtained the percentage increase in risk of lung cancer per $100 \mathrm{~Bq} / \mathrm{m}^{3}$ increase in long term average radon concentration at home from an analysis of data on radon and smoking histories in more than 7000 people with lung cancer and more than 21000 controls in nine European countries. ${ }^{56}$ The absolute risk of death from lung cancer in lifelong non-smokers was taken from a prospective study of more than one million Americans over 20 years, ${ }^{19}$ which provides the most reliable risk estimates for this group. The percentage increase in risk of lung cancer caused by smoking was taken from a UK study of 1000 people with lung cancer and more than 3000 controls. ${ }^{20}$ From official statistics we obtained UK population numbers and numbers of deaths from lung cancer and from all causes for 2006. ${ }^{1}$ Details of the terminology and methods are given in web extra appendix 1 .

\section{Cost effectiveness}

The cost effectiveness analysis adhered to the methodological framework widely considered appropriate in economic evaluation of health interventions. ${ }^{13-15} \mathrm{We}$ constructed a model to estimate lifetime risk of fatal lung cancer before and after preventive measures to reduce radon levels, using the estimated risks of lung cancer. To obtain quality adjusted life years (QALYs) we calculated life years gained and adjusted these using age specific and sex specific normative weights. Calculations allowed for the competing risk of death from other causes. Further details are given in web extra appendix 2.

We included direct costs incurred or saved by homeowners, government departments and agencies including the Health Protection Agency, and the United Kingdom's health service. For new homes, the relevant agencies provided agreed estimates of the current costs of basic preventive measures. For existing homes, remediation costs included the cost of identifying homes targeted by policy, and the capital, maintenance, running, and replacement costs of remedial work. We also included treatment costs for patients with lung cancer, and the healthcare use of patients during any extended life expectancy. We assumed that initial programme costs, including all measurement

\begin{tabular}{|c|c|}
\hline Mean indoor radon concentration in local area† & Current policy requirement $\ddagger$ \\
\hline \multicolumn{2}{|l|}{ New homes: } \\
\hline$\left\langle 52 \mathrm{~Bq} / \mathrm{m}^{3}\left(\ll 3 \%\right.\right.$ of measurements $\left.>200 \mathrm{~Bq} / \mathrm{m}^{3}\right) \S$ & None \\
\hline $52-86 \mathrm{~Bq} / \mathrm{m}^{3}\left(3-9 \%\right.$ of measurements $\left.>200 \mathrm{~Bq} / \mathrm{m}^{3}\right)$ & Basic preventive measures, such as a sealed membrane at ground level \\
\hline At least $87 \mathrm{~Bq} / \mathrm{m} 3$ ( $\geq 10 \%$ of measurements $>200 \mathrm{~Bq} / \mathrm{m}^{3}$ ) & $\begin{array}{l}\text { "Full preventive measures" consisting of basic preventive measures plus installation of } \\
\text { under-floor ventilation, such as fitting a radon sump and pipeף }\end{array}$ \\
\hline \multicolumn{2}{|l|}{ Existing homes: } \\
\hline$\left\langle 64 \mathrm{~Bq} / \mathrm{m}^{3}\left(\left\langle 5 \%\right.\right.\right.$ of measurements $\left.>200 \mathrm{~Bq} / \mathrm{m}^{3}\right)$ & None \\
\hline At least $64 \mathrm{~Bq} / \mathrm{m}^{3}\left(\geq 5 \%\right.$ of measurements $\left.>200 \mathrm{~Bq} / \mathrm{m}^{3}\right)$ & $\begin{array}{l}\text { A series of targeted programmes offer free (government funded) measurements to } \\
\text { homeowners on a rolling basis. If measured radon concentration is }>200 \mathrm{~Bq} / \mathrm{m}^{3} \text {, then } \\
\text { homeowners are advised to remediate at their own expense }\end{array}$ \\
\hline \multicolumn{2}{|c|}{$\begin{array}{l}\text { *Policies in other parts of UK differ slightly. For details see document from Independent Advisory Group on lonising Radiation. } \\
\dagger \text { †uch as a } 1 \mathrm{~km} \text { or } 5 \mathrm{~km} \text { grid square, administrative area or division of postcode system. } \\
\text { †In addition, areas with mean indoor radon concentration more than } 36 \mathrm{~Bq} / \mathrm{m}^{3}\left(>1 \% \text { of measurements }>200 \mathrm{~Bq} / \mathrm{m}^{3} \text { ) have been designated as "radon }\right. \\
\text { affected" areas. The Health Protection Agency recommends that anyone living in such areas should measure the radon concentration in their home anc } \\
\text { remediate if measured radon exceeds } 200 \mathrm{~Bq} / \mathrm{m}^{3} \text {. Employers are required to measure radon concentrations in both new and existing workplaces in } \\
\text { areas designated as radon affected and in underground workplaces in any area, and to restrict exposure if measured radon exceeds } 400 \mathrm{~Bq} / \mathrm{m}^{3} \text { (www } \\
\text { hse.gov.uk/radiation/ionising/radon.htm). } \\
\text { §The distribution of indoor radon measurements over different homes in an area is closely approximated by a log normal distribution, and so a } \\
\text { predictable relation exists between mean indoor radon concentration in an area and percentage of measurements above any particular value. (See } \\
\text { web extra appendix } 1 \text { for further details.) } \\
\text { TThere is no requirement to measure radon concentrations in these homes after they have been built or to activate the sump-for example, by } \\
\text { installing a fan. Therefore, "full protective measures" currently required do not reduce radon concentrations more than basic preventive measures. }\end{array}$} \\
\hline
\end{tabular}


and initial remediation costs, were incurred in the first year. Costs are expressed in 2007 pounds sterling. Input values used for cost effectiveness analyses are summarised in web extra appendix 3.

To calculate the cost effectiveness of various intervention programmes compared with no programme we combined the estimates of effects and costs. Cost effectiveness was calculated as the ratio of net change in cost to net change in outcome, with outcome (lung cancer deaths averted) expressed in terms of life years gained and QALYs gained; this enables comparison of the cost effectiveness of various radon policies with each other and with other public health and healthcare interventions.

We evaluated all policies over 100 years to cover the life time of buildings and human lifespan, with costs discounted to present values at 3.5\% per annum and benefits at $1.5 \%$ per annum, in line with Department of Health guidance. ${ }^{15}$ Benefits were assumed to occur evenly over time, with no lag between reduction of radon levels and starting risk reduction. We examined the uncertainty around the various assumptions and data inputs using one way analysis and probabilistic sensitivity analyses. Additional sensitivity analyses using radon related risks estimated indirectly from studies of exposed miners are presented elsewhere. ${ }^{21}$

We assessed the value for money of radon interventions using the approach advocated by the National Institute for Health and Clinical Excellence (NICE) in England and Wales, where interventions with a cost effectiveness of less than $£ 20000$ per QALY gained are likely to be viewed favourably, whereas those with a cost per QALY gained of more than $£ 30000$ are likely to be viewed unfavourably. ${ }^{22} \mathrm{NICE}$ is mainly concerned with the NHS, but here the costs or savings also fall on other agencies and on households and so are included. Other ways of valuing health gains in UK government departments, such as "statistical life" values to inform decisions on transport safety, or willingness to pay for improved air quality, also give values per year of life in the range $£ 27500$ - $355000 .^{2324}$ Hence we take the range $£ 20000-£ 30000$ per QALY gained to indicate likely upper limits to society's willingness to pay for health gain, irrespective of who incurs the costs.

Potential to reduce the number of deaths from lung cancer

We evaluated the potential of current and possible future policies to reduce the number of deaths from lung cancer in the UK population. We calculated the number of deaths from radon related lung cancer that would arise if the policy were fully implemented throughout the UK and we compared that number with the current number. Details of the methods are given in web extra appendix 1 .

\section{RESULTS}

Deaths from radon related lung cancer

The mean indoor radon concentration in UK homes is $21 \mathrm{~Bq} / \mathrm{m}^{3}$. In 2006, 3.3\% of deaths from lung cancer in the UK ( 1 in 516 of all deaths) were caused by radon in the home. Overall, $48 \%$ of radon related deaths occurred in adults aged 55-74. Most of the remainder occurred in those aged more than 75 , with only $6 \%$ at ages less than 55 , and virtually none below age 35 (see web extra appendix 4). Fifty eight per cent of radon related deaths were in men.

About 1 in 7 of the deaths from radon related lung cancer is caused by radon and not by active smoking (table 2). The remainder are caused jointly by radon and active smoking as the cancer could have been prevented by avoiding exposure to either factor. For lifelong non-smokers living in a home with long term average radon concentration equal to the UK mean of $21 \mathrm{~Bq} / \mathrm{m}^{3}$, the cumulative risk of death from lung cancer by age 75 is $0.42 \%$ (fig 1). For a hypothetical radon concentration of zero the value would reduce slightly to $0.41 \%$, and for homes with concentrations of $200 \mathrm{~Bq} / \mathrm{m}^{3}$ it would increase to $0.53 \%$ and further to $0.66 \%$ and $0.92 \%$ for lifelong non-smokers living in homes with concentrations of $400 \mathrm{~Bq} / \mathrm{m}^{3}$ and $800 \mathrm{~Bq} /$ $\mathrm{m}^{3}$, respectively. For cigarette smokers, the cumulative risk of death from lung cancer by age 75 in the UK when the indoor radon concentration is equal to the UK mean is $15 \%$, and increases to $19 \%$ for a radon concentration of $200 \mathrm{~Bq} / \mathrm{m}^{3}$ and to $23 \%$ and $31 \%$ for cigarette smokers exposed to concentrations of 400 $\mathrm{Bq} / \mathrm{m}^{3}$ and $800 \mathrm{~Bq} / \mathrm{m}^{3}$, respectively. For former smokers the risk is substantially lower than for continuing smokers, even for those stopping as late as age 50, but it remains considerably above the risk for lifelong non-smokers (fig 1). Nearly half of the deaths caused jointly by radon and active smoking occurred in former smokers (table 2), a proportion that will rise in the future if the number of former smokers increases.

If it were possible to measure radon concentrations in all homes in the UK, an estimated $91 \%$ of measurements would be less than 50 (mean 16) Bq/

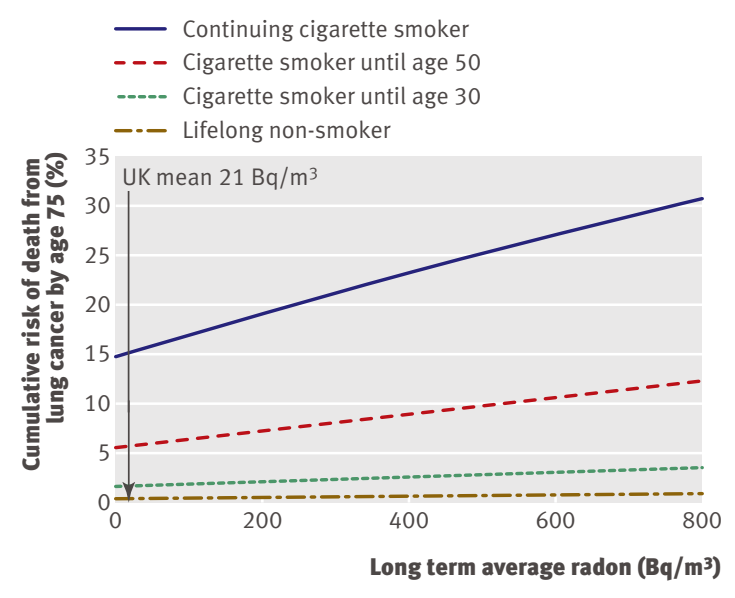

Fig 1| Cumulative risk of death from lung cancer by age 75 according to long term average radon concentration at home for current cigarette smokers, former smokers, and lifelong non-smokers in UK, based on 2006 death rates. The long term average radon concentration in a home is the value that would be obtained if the concentration were measured in the home many times in different years (see also web extra appendix 1) 
Table 2 |Numbers of deaths from lung cancer in United Kingdom, 2006, by cause

\begin{tabular}{|c|c|c|c|c|}
\hline Cause & $\begin{array}{l}\text { No (\%) of } \\
\text { deaths from } \\
\text { lung cancer }\end{array}$ & \multicolumn{3}{|c|}{ Deaths from lung cancer } \\
\hline Not active smoking or indoor radon & $4664^{\star}(13.6)$ & & & \\
\hline Radon but not active smoking & $157 \dagger(0.5)$ & \multirow{4}{*}{$\begin{array}{l}3.3 \% \text { due to } \\
\text { radon§ }\end{array}$} & & \multirow{5}{*}{$\begin{array}{l}86.4 \% \text { due to } \\
\text { active } \\
\text { smoking or } \\
\text { radon }\end{array}$} \\
\hline Active smoking and radonł: & & & \multirow{4}{*}{$\begin{array}{l}85.9 \% \text { due } \\
\text { to active } \\
\text { smoking }\end{array}$} & \\
\hline Current smokers & $532(1.6)$ & & & \\
\hline Former smokers & $421(1.2)$ & & & \\
\hline Active smoking but not indoor radon & $28376(83.1)$ & & & \\
\hline Total No of lung cancer deaths $\mathbb{\|}$ & $34150(100)$ & & & \\
\hline
\end{tabular}

*Including any deaths caused by passive smoking but not by radon.

†Including any deaths caused by passive smoking and radon.

tCancers that would have been avoided by avoidance of either indoor radon or smoking.

$\S$ Mean indoor concentration of radon in UK is $21 \mathrm{~Bq} / \mathrm{m}^{3}$.

TTotal number of deaths from all causes in UK in 2006 was 572 224. Indoor radon is estimated to cause 1110 (that is, $157+532+421$ ) deaths ( 1 in 516 or $0.2 \%$ of deaths from all causes in UK).

$\mathrm{m}^{3}$, with $6 \%$ in the range $50-99(68) \mathrm{Bq} / \mathrm{m}^{3}$, and $2 \%$ in the range 100-199 (133) $\mathrm{Bq} / \mathrm{m}^{3}$. Only an estimated $0.4 \%$ of homes in the UK would have measured radon concentrations 200 (mean 304) $\mathrm{Bq} / \mathrm{m}^{3}$ or higher. Although people living in such homes have a greater risk than those living in homes with lower measurements, few such people exist. The estimated percentage of deaths from radon related lung cancer in homes with measurements of $200 \mathrm{~Bq} / \mathrm{m}^{3}$ or more is $4 \%$, with measurements of $100-199 \mathrm{~Bq} / \mathrm{m}^{3}$ is $9 \%$, and with measurements of $50-99 \mathrm{~Bq} / \mathrm{m}^{3}$ is $17 \%$. The remaining $70 \%$ of deaths from radon related lung cancer are in homes where the measurement would be below $50 \mathrm{~Bq} /$ $\mathrm{m}^{3}$ (fig 2). The Health Protection Agency has designated areas where more than $1 \%$ of measurements exceed $200 \mathrm{~Bq} / \mathrm{m}^{3}$ (that is, mean radon $>36 \mathrm{~Bq} / \mathrm{m}^{3}$ ) as "radon affected," ${ }^{21}$ but $75 \%$ of radon related lung cancers arise elsewhere.

\section{Cost effectiveness of policies for new homes}

Table 3 reports estimates of cost effectiveness for installing basic preventive measures to prevent radon in all new homes during construction in areas where about $3 \%$ of homes have radon measurements above the current action level of $200 \mathrm{~Bq} / \mathrm{m}^{3}$ - that is, areas where the mean indoor radon concentration is $52 \mathrm{~Bq} /$ $\mathrm{m}^{3}$. Practical policies target areas above a certain value

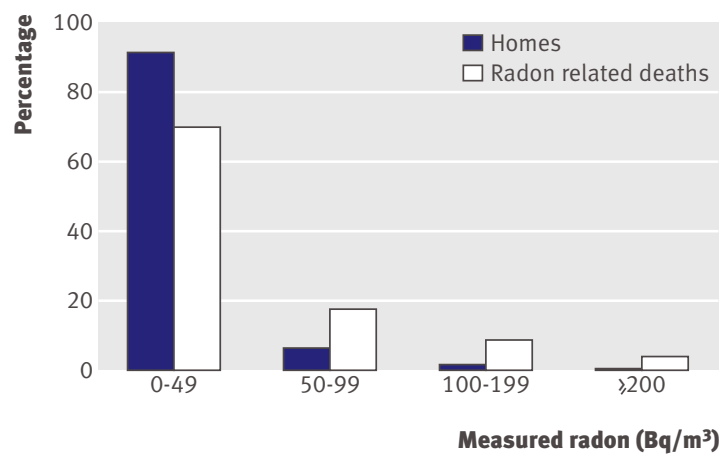

Fig 2 Distributions of measured radon concentrations in UK homes and of deaths from radon related lung cancer rather than areas at a particular value as in this example. However, it is necessary to calculate cost effectiveness at particular values to determine where to set policy thresholds.

The cumulative lifetime risk of death from lung cancer for a member of the general population falls from $6.38 \%$ at pre-prevention radon concentrations to $6.14 \%$ post-prevention, equivalent to a reduction of 5.7 deaths per 1000 households of average size (2.4 occupants) who remediate. This is equivalent to 76.2 life years gained, or 31.2 discounted QALYs gained. The costs per household are the basic preventive measures of $£ 100$ and additional costs to the health system of $£ 177$ from added life expectancy, while $£ 29$ is saved from treatment costs for lung cancers averted, resulting in a net societal cost of $£ 248$ per household. The cost per QALY gained is therefore $£ 7953$ ( $£ 3201$ considering only radon prevention costs and $£ 4752$ considering only NHS costs). This is well below the maximum level that might typically be considered cost effective ( $£ 20000-£ 30000$ per QALY gained).

The societal cost per QALY gained of installing basic measures to prevent radon in new homes decreases as the mean indoor radon concentration in the local area rises, and increases as the mean radon concentration falls (table 4). However, even in areas with a mean radon concentration as low as $10 \mathrm{~Bq} / \mathrm{m}^{3}$, the cost per QALY gained is still only $£ 21400$ ( $£ 16600$ considering preventive measures only and $£ 4800$ considering NHS costs only). When the entire UK is considered, the cost per QALY gained is $£ 11400$ ( $£ 6600$ considering preventive measures only and $£ 4800$ considering NHS costs only). This suggests that a policy of requiring basic preventive measures in all new homes throughout the UK would be highly cost effective.

Figure 3 summarises the results of one way sensitivity analyses of varying eight input values for the cost effectiveness of installing basic preventive measures in all new homes throughout the UK from their baselines. Changes in the cost of treatment for lung cancer, or introducing a latency period for a reduction in risk of lung cancer, have little effect. In contrast, the results are sensitive to the cost and effectiveness of installing basic protection measures, to assumptions regarding the percentage increase in risk of lung cancer per $100 \mathrm{~Bq} /$ $\mathrm{m}^{3}$, and to the discount rates: at $0 \%$ for outcomes and $3.5 \%$ for costs, cost effectiveness falls to $£ 6000$ per QALY gained, whereas at a $6 \%$ discount rate for both costs and outcomes, cost effectiveness increases to $£ 28200$ per QALY gained. At discount rates of 3.5\% for costs and outcomes, as recommended by NICE, ${ }^{22}$ the cost per QALY gained rises to $£ 16100$. Spending more on basic preventive measures-for example, using more gas resistant material or having a stricter inspection regimen - might be worthwhile but only if it produced a substantial additional reduction in radon levels (see web extra appendix 6). A probabilistic sensitivity analysis, in which all variables were varied simultaneously and independently, showed that a policy of basic measures in all new homes has probabilities of being cost effective of $94 \%$ and $99 \%$ 
Table 3 | Cost effectiveness of current government policy to control radon in England. Costs are in pounds sterling

\begin{tabular}{|c|c|c|}
\hline Description & New homes* & $\begin{array}{l}\text { Existing } \\
\text { homes } \dagger\end{array}$ \\
\hline \multicolumn{3}{|l|}{ Lifetime cumulative risk of death from lung cancer (\% per person) } \\
\hline Pre-preventive action & $6.38 \ddagger$ & $7.82 \S$ \\
\hline Post-preventive action & 6.14 & 6.19 \\
\hline \multicolumn{3}{|l|}{ Health gain per 1000 households remediating } \\
\hline Lung cancer deaths averted & 5.7 & 39.0 \\
\hline Total life years gained & 76.2 & 516.9 \\
\hline Total life years gained-discounted & 39.9 & 270.8 \\
\hline Total QALYs gained & 59.6 & 404.7 \\
\hline Total QALYs gained-discounted & 31.2 & 212.0 \\
\hline \multicolumn{3}{|l|}{ Resource use and costs per household remediating } \\
\hline Radon prevention cost & 100 & - \\
\hline No of invitations to measure & - & 333 \\
\hline Invitation costs & - & 550 \\
\hline No of radon measurements & - & 100 \\
\hline Radon measurement cost & - & 4200 \\
\hline Radon remediation cost $\pi$ & - & 2051 \\
\hline Subtotal: invitation, measurement, and remediation costs & 100 & 6801 \\
\hline NHS lung cancer treatment costs averted $\boldsymbol{\Psi}$ & 29 & 195 \\
\hline Other NHS costs incurred by added life expectancy & 177 & 1203 \\
\hline Net cost - - societal: & 248 & 7809 \\
\hline To NHS & 148 & 1008 \\
\hline To Health Protection Agency & - & 4750 \\
\hline To households & 100 & 2051 \\
\hline \multicolumn{3}{|l|}{ Cost effectiveness } \\
\hline Cost per life year gained-societal & 6226 & 28833 \\
\hline Cost per QALY gained_-societal: & 7953 & 36829 \\
\hline To NHS & 4752 & 4752 \\
\hline $\begin{array}{l}\text { To homeowners, ** and to Health Protection Agency and government } \\
\text { departmentst† }\end{array}$ & 3201 & 32077 \\
\hline
\end{tabular}

$£ 1(€ 1.1 ; \$ 1.5)$. QALY=quality adjusted life year.

${ }^{*}$ Basic preventive measures in all new homes in areas where $3 \%$ of homes have measured radon $>200 \mathrm{~Bq} / \mathrm{m}^{3}$ (that is, mean indoor radon $52 \mathrm{~Bq} / \mathrm{m}^{3}$ ).

†Inviting households in existing homes to measure in areas where $5 \%$ of homes have measured radon $>200 \mathrm{~Bq} /$ $\mathrm{m}^{3}$ (that is, mean indoor radon $64 \mathrm{~Bq} / \mathrm{m}^{3}$ ) and recommending remediation if measurement is above current action level of $200 \mathrm{~Bq} / \mathrm{m}^{3}$.

fLifetime cumulative risk at mean indoor radon $52 \mathrm{~Bq} / \mathrm{m}^{3}$ for all homes in area.

§Lifetime cumulative risk at mean indoor radon $308 \mathrm{~Bq} / \mathrm{m}^{3}$ for homes with measurements $1200 \mathrm{~Bq} / \mathrm{m}^{3}$.

ๆDiscounted.

$\star \star$ Radon prevention in new homes, or remediation costs in existing homes.

t†Invitation and measurement costs in existing homes.
The mean indoor radon concentration in an area determines the number of houses that have to be measured to identify one with concentrations over the action level. Under current policy, invitations to measure typically have a $30 \%$ acceptance rate, and recommendations to remediate a $20 \%$ uptake. ${ }^{2526}$ Therefore in an area with a mean indoor radon concentration of $64 \mathrm{~Bq} / \mathrm{m}^{3}$ - that is, where $5 \%$ of measurements exceed $200 \mathrm{~Bq} / \mathrm{m}^{3}$ - 333 invitations to measure would be required to yield 100 homes measured, five above $200 \mathrm{~Bq} / \mathrm{m}^{3}$, and one remediating. These costs, together with remediation costs, come to a discounted total of $£ 6801$. Another $£ 1203$ is incurred in healthcare costs during added life expectancy, whereas $£ 195$ is saved from averted treatment costs for lung cancer. Consequently the net cost is $£ 7809$ per household remediating. The resulting cost per discounted QALY gained is £36 829 ( $£ 32077$ considering radon measurement and remediation costs only and $£ 4752$ considering NHS costs only). This is above the maximum value that is typically considered good value for money when assessing alternative ways of improving health.

The cost per QALY gained of remediating existing homes varies as the mean radon concentration in the area changes, and for any given mean radon concentration the cost per QALY also varies if the action level is changed. This is partly because the action level influences the mean radon concentration in homes remediating, but also because the action level determines the number of homes advised to remediate and therefore influences the number of remediating homes over which the initial detection costs can be spread. Reducing the current action level to $100 \mathrm{~Bq} / \mathrm{m}^{3}$ might make a policy for existing homes cost effective for areas with a mean indoor radon concentration of $60 \mathrm{~Bq} / \mathrm{m}^{3}$. The cost per QALY would be $£ 29800$ compared with $£ 36800$ for the current policy in areas with a mean radon concentration of $64 \mathrm{~Bq} / \mathrm{m}^{3}$ (table 5 ).

Figure 3 shows the results of one way sensitivity analyses on invitations to measure existing homes in areas with a mean indoor radon concentration of 60 $\mathrm{Bq} / \mathrm{m}^{3}$ and a recommendation to remediate if measured radon is above an action level of $100 \mathrm{~Bq} / \mathrm{m}^{3}$. It is evident that cost effectiveness is particularly sensitive to risk of radon related lung cancer and discount rates and that it is also influenced by the proportion of homes over the action level undergoing remediation. At discount rates of $3.5 \%$ for costs and outcomes, as recommended by $\mathrm{NICE},{ }^{22}$ the cost per QALY gained rises to $£ 36100$. A probabilistic sensitivity analysis showed that this policy has probabilities of being cost effective of $16 \%$ and $54 \%$ when decision makers are prepared to spend up to $£ 20000$ and $£ 30000$ per QALY gained, respectively (see web extra appendix $7 \mathrm{~b})$.

The health benefits of interventions against radon vary greatly depending on the number and characteristics of people in the home. For new homes this has little relevance to policy. For existing homes, however, the relevance may be substantial. Table 6 shows cost equivalent to a reduction of 39.0 deaths per 1000 households of average size who remediate, which in turn is equivalent to 516.9 life years gained, or 212.0 discounted QALYs gained. 

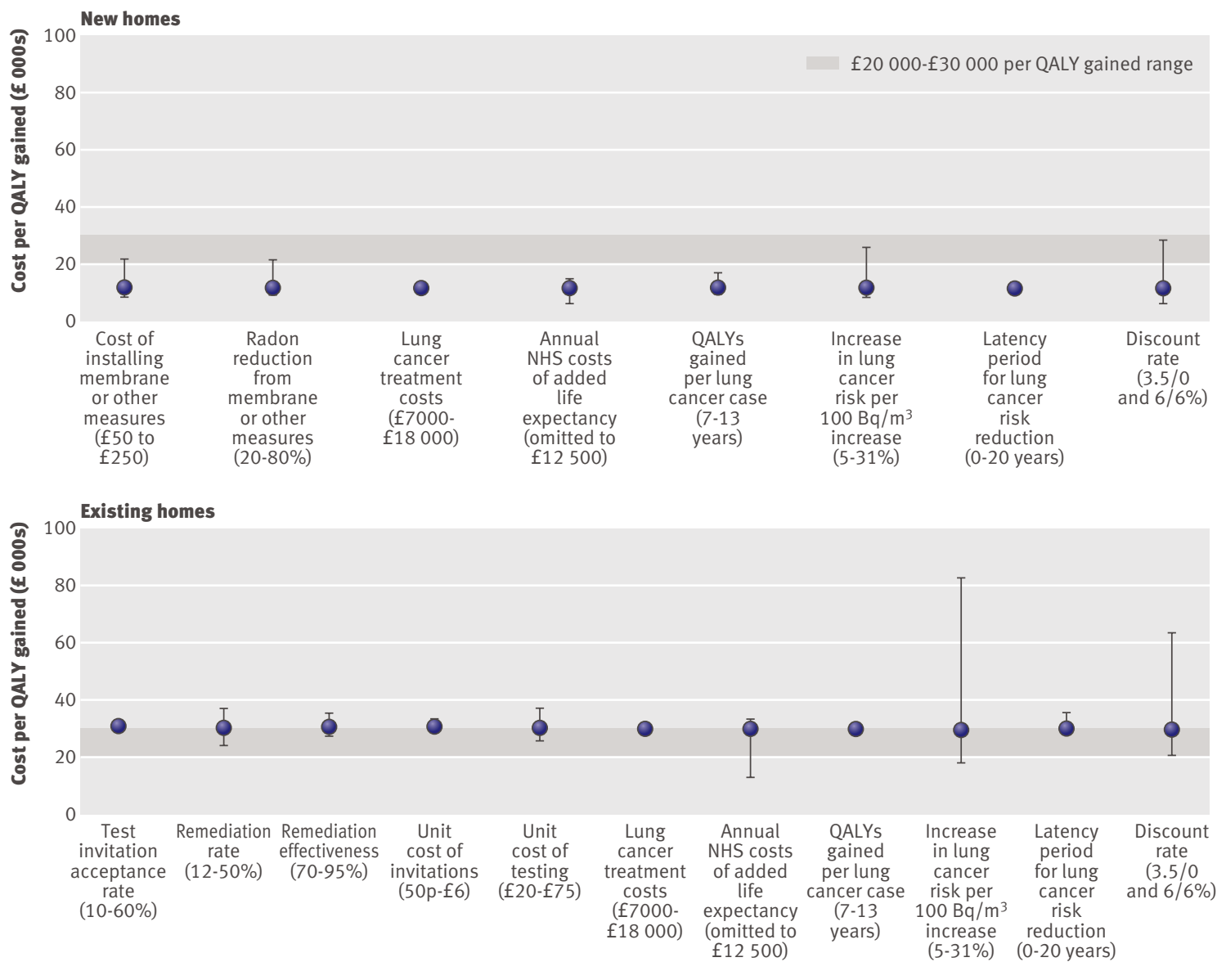

Fig 3 Sensitivity of cost effectiveness to changes in input values of installing basic preventive measures in all new homes throughout UK (top), and of invitations to existing homes to measure and recommendation to remediate for measurements above an action level of $100 \mathrm{~Bq} / \mathrm{m}^{3}$ in areas with mean indoor radon $60 \mathrm{~Bq} / \mathrm{m}^{3}$ (bottom)

Table $4 \mid$ Cost per quality adjusted life year (QALY) gained (discounted) of requiring basic measures to prevent radon in new homes by mean indoor radon concentration in area

\begin{tabular}{lcc}
$\begin{array}{l}\text { Mean indoor radon } \\
\text { concentration in local } \\
\text { area (Bq/m3) }\end{array}$ & $\begin{array}{c}\text { \% of national housing } \\
\text { stock in areas with } \\
\text { gained (discounted) }\end{array}$ & $\begin{array}{c}\text { mean at or above this } \\
\text { value }\end{array}$ \\
\hline 10 & 21400 & 87.5 \\
\hline 20 & 13100 & 39.6 \\
\hline 30 & 10300 & 16.7 \\
\hline $36^{*}$ & 9400 & 10.3 \\
\hline 40 & 8900 & 7.6 \\
\hline 50 & 8100 & 3.7 \\
\hline $52 \dagger$ & 8000 & 3.2 \\
\hline 60 & 7500 & 1.9 \\
\hline $64 \ddagger$ & 7400 & 1.5 \\
\hline 70 & 7100 & 1.0 \\
\hline 80 & 6800 & 0.6 \\
\hline $87 \S$ & 6700 & 0.4 \\
\hline 90 & 6600 & 0.4 \\
\hline Entire UK: & & 100 \\
\hline 21 & 11400 & \\
\hline
\end{tabular}

$£ 1(€ 1.1 ; \$ 1.5)$.

* $1 \%$ of measurements $>200 \mathrm{~Bq} / \mathrm{m}^{3}$.

$\dagger 3 \%$ of measurements $>200 \mathrm{~Bq} / \mathrm{m}^{3}$, and limit of current policy.

$\$ 5 \%$ of measurements $>200 \mathrm{~Bq} / \mathrm{m}^{3}$.

$\S 10 \%$ of measurements $>200 \mathrm{~Bq} / \mathrm{m}^{3}$. effectiveness for the total population of remediation in areas with a mean indoor radon concentration of 60 $\mathrm{Bq} / \mathrm{m}^{3}$ and with an action level of $100 \mathrm{~Bq} / \mathrm{m}^{3}$ for a household of average size. The calculation has been repeated for hypothetical populations consisting entirely of lifelong non-smokers and entirely of current cigarette smokers. It is evident that remediation is likely to be highly cost effective for current cigarette smokers $(<£ 14000$ per QALY gained), but very cost ineffective for never smokers $(>£ 173000$ per QALY gained). For former smokers, cost effectiveness will be between the values for never smokers and current smokers. In practice, smoking status may be unchanged over long periods for particular households, but vary for a given house as ownership changes.

\section{Cost effectiveness of policies for new homes in high radon} areas

In areas where, in the absence of any preventive measures, at least $10 \%$ of homes would have measured radon concentrations above $200 \mathrm{~Bq} / \mathrm{m}^{3}$ - that is, where the mean radon is at least $87 \mathrm{~Bq} / \mathrm{m}^{3}$, the current policy for full preventive measures requires fitting a means of under-floor ventilation, such as a sump and associated pipework, in addition to basic preventive measures (see table 1). This is to facilitate the later installation of 
Table 5 | Effect on cost per quality adjusted life year (QALY) gained (discounted) of varying both targeted area and action level, for policy of inviting existing households in targeted area to measure and advising remediation if measurement is above action level

\begin{tabular}{|c|c|c|c|c|c|c|c|}
\hline \multirow{3}{*}{$\begin{array}{l}\text { Targeted area } \\
\text { ( } \mathrm{Bq} / \mathrm{m}^{3} \text { mean } \\
\text { indoor radon) }\end{array}$} & \multicolumn{7}{|c|}{ Cost (£) per QALY gained (discounted) } \\
\hline & \multicolumn{7}{|c|}{ Action level ( $\mathrm{Bq} / \mathrm{m}^{3}$ measured value) } \\
\hline & $25 \mathrm{~Bq} / \mathrm{m}_{3}$ & $50 \mathrm{~Bq} / \mathrm{m}_{3}$ & $100 \mathrm{~Bq} / \mathrm{m}_{3}$ & $150 \mathrm{~Bq} / \mathrm{m}_{3}$ & $200 \mathrm{~Bq} / \mathrm{m}_{3}$ & $300 \mathrm{~Bq} / \mathrm{m}_{3}$ & $400 \mathrm{~Bq} / \mathrm{m}_{3}$ \\
\hline 20 & 85200 & 105600 & 285200 & 744300 & 1682500 & 6271900 & 17840700 \\
\hline 30 & 60600 & 56900 & 86100 & 159700 & 293800 & 851800 & 2056100 \\
\hline $36^{*}$ & 53100 & 47200 & 58900 & 93400 & 154700 & 395900 & 885400 \\
\hline 40 & 49300 & 43000 & 49200 & 71600 & 111500 & 264300 & 564600 \\
\hline 50 & 42200 & 36200 & 36200 & 44900 & 61200 & 121700 & 233900 \\
\hline $52 \dagger$ & 41000 & 35100 & 34400 & 41600 & 55400 & 106500 & 200200 \\
\hline 60 & 37200 & 31900 & 29800 & 33400 & 41300 & 70600 & 123300 \\
\hline $64 \ddagger$ & 35600 & 30700 & 28200 & 30700 & $36800 \S$ & 60000 & 101100 \\
\hline 70 & 33400 & 28900 & 26000 & 27400 & 31500 & 47600 & 76100 \\
\hline 80 & 30400 & 26600 & 23500 & 23700 & 25900 & 35500 & 52500 \\
\hline $87 \rrbracket$ & 28500 & 25200 & 22100 & 21800 & 23200 & 29900 & 42000 \\
\hline 90 & 27900 & 24700 & 21700 & 21300 & 22400 & 28400 & 39200 \\
\hline 100 & 25900 & 23200 & 20300 & 19500 & 20100 & 23900 & 31200 \\
\hline
\end{tabular}

$£ 1(€ 1.1 ; \$ 1.5)$. Calculations carried out for total population and assume that never smokers, current smokers, and former smokers are equally likely to remediate. See table 6 for separate calculations according to smoking category. Calculations also assume that percentage reduction in radon concentration that would result from remediation in homes with pre-remediation concentrations of $25 \mathrm{~Bq} / \mathrm{m}^{3}, 50 \mathrm{~Bq} / \mathrm{m}^{3}$, or $100 \mathrm{~Bq} / \mathrm{m}^{3}$ would be similar to that achieved at higher preinstallation concentrations (that is, $85 \%$ ), although little information is available on this. Entries in bold denote most cost effective action level for each targeted area. Entries in italics have cost per QALY gained between $£ 20000$ and $£ 30000$.

${ }^{*} 1 \%$ of measurements $>200 \mathrm{~Bq} / \mathrm{m}^{3}$.

$\dagger 3 \%$ of measurements $>200 \mathrm{~Bq} / \mathrm{m}^{3}$.

$\$ 5 \%$ of measurements $>200 \mathrm{~Bq} / \mathrm{m}^{3}$.

$\S$ Limit of current policy.

\10\% of measurements $>200 \mathrm{~Bq} / \mathrm{m}^{3}$.

active preventive measures (such as an electric fan) if the house still has a high radon concentration. However, as the current policy does not require the measurement of radon nor installation of active measures, the effectiveness is similar to the policy for basic measures although the cost is higher. Therefore the incremental cost effectiveness of full preventive measures in such areas compared with the policy for basic measures is infinite.

A more logical policy for full preventive measures would require radon to be measured in such houses after construction and occupation, and the installation of active measures, such as an electric fan, when appropriate. At the current action level for radon of 200 $\mathrm{Bq} / \mathrm{m}^{3}$ such a policy would have a cost per QALY gained of $£ 53500$ in areas with a mean radon concentration of $87 \mathrm{~Bq} / \mathrm{m}^{3}$. The poor cost effectiveness occurs because basic preventive measures will already have halved radon levels, thereby reducing the number of homes with measurements above any particular action level and so increasing the cost of detecting them. The cost of fitting large numbers of sumps and pipework to all homes in the area, plus the high lifetime costs of running and maintaining active measures such as electric fans when required, also adversely affect cost effectiveness. As with policies for existing homes, cost effectiveness could be improved if the action level were reduced to $100 \mathrm{~Bq} / \mathrm{m}^{3}$ or $50 \mathrm{~Bq} / \mathrm{m}^{3}$. At such action levels the policy would be cost effective just below $£ 30000$ per QALY in areas with a mean radon concentration $90 \mathrm{~Bq} / \mathrm{m}^{3}$, provided that $100 \%$ compliance could be achieved (see web extra appendix 5). If
$100 \%$ compliance could not be achieved, cost effectiveness would be poorer and the policy would only be cost effective in areas with even higher mean radon concentration.

An alternative policy might be to install only basic measures during construction, measure radon in all homes in specified areas, and then retrofit sumps and pipework in addition to electric fans in homes still above the action level. The cost of retrofitting would be higher than the cost of fitting during construction, but the work would need to be done in fewer homes. However, compliance might also fall due to the added disruption involved. Our calculations suggest that these factors approximately cancel out, giving this policy no advantage. ${ }^{21}$

\section{Potential for different radon policies to reduce deaths} from lung cancer in the UK

Table 7 summarises the estimated effect of current radon control policies in averting deaths from lung cancer in the UK and the effect of adopting cost effective policies. Ten years of the current policy for new homes (that is, installing basic measures in areas with mean indoor radon concentration of at least 52 $\mathrm{Bq} / \mathrm{m}^{3}$ ) would avert only five deaths per year across the entire UK population, increasing by 0.5 deaths per year for each year of the policy. In contrast, the suggested policy of basic measures in all new homes would avert 44 deaths from lung cancer per year after 10 years of that policy, and this number would increase by 4.4 deaths per year as the policy continued so that a cumulative total of nearly 1000 deaths would be 
Table 6 |Cost effectiveness of remediating existing homes for total population and for households consisting entirely of never smokers or entirely of current cigarette smokers, based on inviting existing households in areas with a mean indoor radon concentration of 60 $\mathrm{Bq} / \mathrm{m}^{3}$ to measure, and remediation advised if measurement is above an action level of 100 $\mathrm{Bq} / \mathrm{m}^{3}$. Costs are in pounds sterling

\begin{tabular}{|c|c|c|c|}
\hline Description & Total population* & $\begin{array}{l}\text { Never smokers only } \\
\text { in household } \dagger\end{array}$ & $\begin{array}{c}\text { Current cigarette } \\
\text { smokers only in } \\
\text { household } \neq\end{array}$ \\
\hline \multicolumn{4}{|c|}{ Lifetime cumulative risk of death from lung cancer (\% per person) } \\
\hline Pre-remediation & 7.13 & 0.94 & 28.52 \\
\hline Post-remediation & 6.09 & 0.80 & 24.81 \\
\hline \multicolumn{4}{|c|}{ Health gain per 1000 households remediating } \\
\hline Lung cancer cases averted & 25.1 & 3.4 & 89.2 \\
\hline Total QALYs gained§ & 136.3 & 20.2 & 352.3 \\
\hline \multicolumn{4}{|c|}{ Resource use and costs per household remediating§ } \\
\hline $\begin{array}{l}\text { Invitation, measurement, and } \\
\text { remediation costs }\end{array}$ & 3414 & 3414 & 3414 \\
\hline $\begin{array}{l}\text { NHS lung cancer treatment costs } \\
\text { averted }\end{array}$ & 126 & 17 & 447 \\
\hline $\begin{array}{l}\text { Other NHS costs incurred by added life } \\
\text { expectancy }\end{array}$ & 774 & 110 & 1870 \\
\hline Net cost-societal & 4062 & 3506 & 4836 \\
\hline \multicolumn{4}{|l|}{ Cost effectiveness§ } \\
\hline Cost per QALY gained-societal: & 29789 & 173720 & 13727 \\
\hline To NHS & 4752 & 4590 & 4037 \\
\hline $\begin{array}{l}\text { To homeowners, Health Protection } \\
\text { Agency, and government departments }\end{array}$ & 25037 & 169130 & 9690 \\
\hline
\end{tabular}

QALY=quality adjusted life year.

${ }^{*}$ Calculated using age specific and sex specific lung cancer death rates for entire UK population.

tCalculated using age specific and sex specific lung cancer death rates for a population of lifelong nonsmokers. ${ }^{19}$

$\ddagger$ Calculated using age specific and sex specific deaths from lung cancer for current cigarette smokers in UK. Rates were derived from observed age specific and sex specific lung cancer death rates for 2006 for the total UK population, estimates of lung cancer death rates for lifelong non-smokers, ${ }^{19}$ estimates of relative risks for UK men with differing smoking habits compared with continuing cigarette smokers, ${ }^{20}$ and estimates of proportion of population according to smoking status for categories of age and sex. ${ }^{2131}$

$\S$ Discounted.
Kingdom. ${ }^{56}$ We estimate that radon is likely to be a cause of about 1100 deaths per year in the UK (about $3.3 \%$ of deaths from lung cancer, and $0.2 \%$ of all deaths). In most other countries indoor radon concentrations are higher than in the $\mathrm{UK}^{2}$ and the proportions of deaths attributable to radon are likely to be correspondingly higher. For the 27 countries of the European Union, the mean indoor radon concentration is around $55 \mathrm{~Bq} / \mathrm{m}^{3}$, suggesting that around $8 \%$ of deaths from lung cancer or 18000 deaths each year are attributable to radon. Indoor radon is therefore a substantial public health issue. In most countries the distribution of indoor radon concentrations is highly skewed, with a small proportion of homes having much higher concentrations than the mean. Policy to date, both in the UK and elsewhere, has usually focused on these high concentrations. ${ }^{827}$ As a result, most radon related lung cancers, which are caused chiefly by the lower radon levels experienced by most of the population, have not been addressed.

\section{Policy implications of results}

Radon gas is a health hazard that can be reduced by intervention. It is therefore appropriate to evaluate policies to control radon using the methods now routinely used to evaluate other health interventions. Our results indicate that current government policy in England of requiring basic preventive measures in all new homes where the mean radon concentration is at least $52 \mathrm{~Bq} / \mathrm{m}^{3}$ is highly cost effective compared with typical maximum values usually considered cost effective in other public health and healthcare interventions. Furthermore, such a policy could be extended to all areas of the UK and still remain well within the maximum value generally regarded as cost effective. In south west England, where preventive measures in new homes are already required, the material and labour costs involved may have fallen over time, and it is likely that preventive measures also reduce exposure to damp and mould, providing additional health and economic benefits. ${ }^{28}$ Both of these factors would further improve the cost effectiveness of basic measures to prevent radon. It would therefore be appropriate for a policy of basic preventive measures against radon in all new homes to be incorporated into the UK building regulations, which are due to be reconsidered shortly. ${ }^{29}$

The current policy of full preventive measures for new homes in high radon areas in England (table 1) does not reduce radon concentrations more than basic measures alone, despite incurring some additional costs. Its incremental cost effectiveness compared with basic measures is therefore infinite. An alternative policy for high radon areas that also required a radon measurement and installation of active measures such as an electric fan in homes where the measurement was above a certain level would, in principle, be more appropriate. However, even if active measures could be installed in 100\% of the relevant homes, such a policy would have cost effectiveness below $£ 30000$ per QALY only in areas where the mean radon

Direct evidence now shows that indoor radon causes lung cancer in the general population not only at high concentrations but also at concentrations below 200 $\mathrm{Bq} / \mathrm{m}^{3}$, the current action level for homes in the United 
Table $7 \mid$ Total numbers of deaths from lung cancer that would be averted by various radon policies if they were implemented throughout UK

Total No of lung cancer deaths potentially averted every year*

Policy

New homes, assuming 200000 built each year

Current government policy in England: installation of basic radon preventive

measures in areas with mean indoor radon concentration $52 \mathrm{~Bq} / \mathrm{m}^{3}$ or highert:

\begin{tabular}{lc}
\hline By 1 year of policy & 0.5 \\
\hline By 2 years of policy & $2 \times 0.5$ \\
\hline Total by 10 years of policy & $\begin{array}{c}5, \text { increasing } \\
\text { by } 0.5 \text { each year }\end{array}$ \\
\hline
\end{tabular}

Basic radon preventive measures throughout UK:

\begin{tabular}{lc}
\hline By 1 year of policy & 4.4 \\
\hline By 2 years of policy & $2 \times 4.4$ \\
\hline Total by 10 years of policy & $\begin{array}{c}44, \text { increasing } \\
\text { by } 4.4 \text { each year }\end{array}$ \\
\hline
\end{tabular}

Possible policy for high radon areas, requiring basic preventive measures plus

fitting a means of under-floor ventilation such as a radon sump and pipe, together

with measurement of radon level after occupation and installation of fan when

measurement exceeds action levelł:

\begin{tabular}{lc} 
By 1 year of policy & 0.03 \\
\hline By 2 years of policy & $2 \times 0.03$ \\
\hline Total by 10 years of policy & $\begin{array}{c}0.3 \text {, increasing } \\
\text { by } 0.03 \text { each year }\end{array}$ \\
\hline
\end{tabular}

\section{Existing homes}

Current government policy in England: targeting invitations to measure in areas

with mean radon concentration $64 \mathrm{~Bq} / \mathrm{m}^{3}$ or higher§ and recommending

remediation when measurement $>200 \mathrm{~Bq} / \mathrm{m}^{3}$, assuming $30 \%$ acceptance rate and

$20 \%$ remediation rate:

After policy fully implemented $\boldsymbol{T}$ 0.9

Effect of targeting invitations to measure in areas with mean indoor radon

concentration $60 \mathrm{~Bq} / \mathrm{m}^{3}$ or higher and recommending remediation when

measurement $>100 \mathrm{~Bq} / \mathrm{m}^{3}$, assuming $30 \%$ acceptance rate and $20 \%$ remediation rate:

After policy fully implemented 2.1

Effect of targeting invitations to measure in areas with mean indoor radon

concentration $60 \mathrm{~Bq} / \mathrm{m}^{3}$ and recommending remediation when measurement $>100$

$\mathrm{Bq} / \mathrm{m}^{3}$, but with acceptance rate increased from $30 \%$ to $60 \%$ and remediation rate increased from $20 \%$ to $50 \%$ :

After policy fully implemented 10.4

*Installing radon preventive measures in new homes or reducing radon concentration in existing homes will avert radon induced lung cancers in every subsequent year.

tAt least $3.0 \%$ of homes with measurements $>200 \mathrm{~Bq} / \mathrm{m}^{3}$. Current government policy in England also requires provision for under-floor ventilation, such as a sump, in homes in areas with mean indoor radon concentration $87 \mathrm{~Bq} / \mathrm{m}^{3}$ or higher (that is, at least $10 \%$ of measurements $2200 \mathrm{~Bq} / \mathrm{m}^{3}$ ). At present there is no requirement either to measure the subsequent radon concentration or to activate the extra measures. Therefore such a policy has effectiveness similar to installation of basic measures only, but it has a higher cost. It is therefore not cost effective compared with a policy of requiring only basic preventive measures.

$\ddagger$ Results shown for areas with a mean radon concentration of $90 \mathrm{~Bq} / \mathrm{m}^{3}$ or higher, an action level of $100 \mathrm{~Bq} / \mathrm{m}^{3}$, and assuming $100 \%$ compliance. Lung cancers averted are additional to those averted by basic radon preventive measures.

§At least $5 \%$ of homes with measurements $>200 \mathrm{~Bq} / \mathrm{m}^{3}$.

TThat is, measurement offered in all areas to be targeted and all remediation carried out.

concentration before the installation of basic preventive measures was above about $90 \mathrm{~Bq} / \mathrm{m}^{3}$. If the distribution of radon concentrations in new homes in the UK is similar to that of existing homes, this would apply to only about $0.4 \%$ of new homes (table 4 ). Therefore it is not surprising that its potential to reduce lung cancer mortality is limited (table 7).

For existing homes, current government policy for England has cost effectiveness above the maximum value usually accepted in other public health and healthcare interventions. Lowering the action level from its current value of $200 \mathrm{~Bq} / \mathrm{m}^{3}$ to $100 \mathrm{~Bq} / \mathrm{m}^{3}$ would improve cost effectiveness and might bring it down to just below $£ 30000$ per QALY in areas with a meanindoor radon concentration of $60 \mathrm{~Bq} / \mathrm{m}^{3}$ (table 5). There would be a further improvement in cost effectiveness if the proportion of households carrying out remediation when the measured radon exceeded the action level (to date around $20 \%{ }^{26}$ ) could be increased (fig 3). This might be achieved through better advice and support to homeowners who have been recommended to remediate. Other methods, such as requiring homeowners throughout the country to disclose all radon measurements to potential purchasers when selling the home, might also increase remediation rates.

At present, public funding is available for radon measurement and mapping, but remediation is at the homeowner's own expense. Recent survey data indicate that the most common reason given for not remediating after being advised to do so is the likely cost. ${ }^{21}$ Grants towards remediation, similar to insulation schemes or disability adaptations, would probably result in higher remediation rates and might be justified on the grounds that radon remediation has health benefits to future as well as current home occupiers. Against this, however, a documented low radon concentration might be favourably reflected in the house price and so materially benefit homeowners, especially in high radon areas.

\section{Strengths and limitations of study}

Our methods for evaluating cost effectiveness diverge in some important respects from those currently used by agencies such as NICE, which is primarily concerned only with healthcare costs directly attributable to an intervention of interest. Here it was necessary to include direct costs incurred by homeowners, who typically bear the cost of taking remedial action, as well as those of other local and central government departments involved in radon prevention and remediation, and of builders. As NICE becomes increasingly involved in issuing guidance on public health programmes and interventions, ${ }^{30}$ this wider societal perspective may become more common.

About six in seven deaths from radon related lung cancer are caused jointly by radon and active smoking (table 2). The analyses presented here assume that those in whom lung cancer is averted by prevention or remediation have smoking habits, and therefore lung cancer risks, typical of the total population. This is likely to be the case for prevention in new homes. For existing homes, however, a recent study has shown that remediation rates among homeowners who are lifelong non-smokers are about twice those of homeowners who are current smokers. ${ }^{21}$ This suggests that the cost effectiveness of remediation in existing homes may in practice be even less favourable than indicated by our analyses, possibly by a substantial amount. Future changes in the prevalence of smoking, or in the average size of households, would also affect our cost effectiveness estimates. Our estimates might also be affected if housing type and smoking habits were 


\section{WHAT IS ALREADY KNOWN ON THIS TOPIC}

Radon gas in ordinary homes increases the risk of lung cancer, particularly for smokers

Current UK policies to control radon in the home focus on radon concentrations $>200 \mathrm{~Bq} / \mathrm{m}^{3}$ while neglecting the lower levels experienced by most of the population

Previous economic evaluations of radon control policies have not used modern methodology with recent data

\section{WHAT THIS STUDY ADDS}

About 1100 deaths from lung cancer in the UK each year are related to radon, but less than $5 \%$ of these arise from radon concentrations $>200 \mathrm{~Bq} / \mathrm{m}^{3}$

A policy requiring basic measures to prevent radon in all new homes throughout the UK would be highly cost effective, and would contribute to reducing lung cancer mortality

Policies to identify and remediate existing homes with high radon concentrations are unlikely to be cost effective, and have limited potential to reduce lung cancer mortality in the UK

correlated-for example, if more smokers live in flats that may have lower average radon levels. At present insufficient information is available on this.

Our analyses consider deaths only from lung cancer, and so do not capture the quality of life loss and costs associated with non-fatal lung cancers. Current five year survival from lung cancer in England is about 7\%, and so this effect is unlikely to be large, but future work could incorporate non-fatal lung cancers in the analyses.

We have considered only radon levels at home. This is partly because radon concentrations are usually higher in small buildings, such as houses, than in larger ones, and because most people spend more time at home than in any other building. However, as the installation of basic preventive measures in new homes is highly cost effective, it is likely that installation of basic measures to prevent radon would be cost effective in other new buildings, such as schools and workplaces. Similarly, policies for radon remediation in other existing buildings are unlikely to be cost effective except in areas with high radon levels.

\section{Conclusions and policy recommendations}

We conclude that basic preventive measures against radon in new homes is likely to be a highly cost effective public health intervention measure, with the potential to make a modest but worthwhile contribution to reducing the annual number of deaths from lung cancer in the UK, alongside existing policies to reduce smoking. UK radon concentrations are lower than those in most other countries and so similar policies are likely to be even more cost effective elsewhere, depending on the extent of smoking related lung cancer. In contrast, the case in the UK for additional preventive measures in new homes in high radon areas, or for policies to remediate in existing homes, is at present less clear and the potential of such policies for reducing the number of deaths from radon related lung cancer is limited.
We thank colleagues in the Health Economics Research Centre and the Clinical Trial Service Unit, members of the Committee on Medical Aspects of Radiation in the Environment, members of the Radon Subgroup of the Health Protection Agency's Independent Advisory Group on Ionising Radiation and its reviewers, and staff of the Health Protection Agency's Radiation Protection Division for helpful comments.

Contributors: SD and AG had the original idea for this study. SD and PMCG designed the methodology for calculating the number of deaths from radon related lung cancer, which was carried out by PMcG. AG and SD designed the economic modelling, which was carried out by AG and SR. SD, AG and SR designed the analysis to estimate the numbers of deaths from lung cancer that would be averted by various radon policies, which was carried out by SR. AG and SD wrote the report with input from SR and PMcG. All authors reviewed and approved the final report. AG and SD are the guarantors.

Funding: This work was supported by Cancer Research UK [grant Nos C500/A10573, A10293], the Medical Research Council [grant No E270/4] the European Commission sixth framework programme (project: alpha risk grant No 516483 (FI6R)), and the National Institute for Health Research. The funders had no role in the design of the study, carrying out the analysis, or the decision to submit for publication.

Competing interests: None declared.

Ethical approval: Not required.

Provenance and peer review: Not commissioned; externally peer reviewed.

1 Cancer Research UK. Cancer statistics. http://info.cancerresearchuk. org/cancerstats/ 2008

2 United Nations Scientific Committee on the Effects of Atomic Radiation. Sources and effects of ionizing radiation. UNSCEAR 2000 Report to the General Assembly, with Scientific Annexes. Vol 1: sources. New York: United Nations, 2000.

3 Committee on Biological Effects of lonising Radiation. Health effects of exposure to indoor radon. Washington: United States National Academy of Sciences, National Research Council, National Academy Press, 1999.

4 United Nations Scientific Committee on the Effects of Atomic Radiation. UNSCEAR 2006 Report to the General Assembly, with Scientific Annexes. Vol 1: effects of ionizing radiation. New York: United Nations, 2008.

5 Darby S, Hill D, Auvinen A, Barros-Dios JM, Baysson H, Bochicchio F, et al. Radon in homes and risk of lung cancer: collaborative analysis of individual data from 13 European case-control studies. BMJ 2005;330:223-8.

6 Darby S, Hill D, Deo H, Auvinen A, Barros-Dios IM, Baysson $\mathrm{H}$, et al. Residential radon and lung cancer-detailed results of a collaborative analysis of individual data on 7148 persons with lung cancer and 14,208 persons without lung cancer from 13 epidemiologic studies in Europe. Scand I Work Environ Health 2006;32(suppl 1):1-83.

7 Naismith SP, Miles JC, Scivyer CR. The influence of house characteristics on the effectiveness of radon remedial measures. Health Phys 1998;75:410-6.

8 Akerblom G. Radon legislation and national guidelines. Report 99:18. Stockholm: Swedish Radiation Protection Institute, 1999.

9 Ford ES, Kelly AE, Teutsch SM, Thacker SB, Garbe PL. Radon and lung cancer: a cost-effectiveness analysis. Am J Public Health 1999;89:351-7

10 Kennedy CA, Gray AM, Denman AR, Phillips PS. A cost-effectiveness analysis of a residential radon remediation programme in the United Kingdom. Br J Cancer 1999;81:1243-7.

11 Coskeran T, Denman A, Phillips P, Tornberg R. A cost-effectiveness analysis of domestic radon remediation in four primary care trusts located in Northamptonshire, UK. Health Policy 2005;71:43-56.

12 Stigum H, Strand T, Magnus P. Should radon be reduced in homes? A cost-effect analysis. Health Phys 2003;84:227-35.

13 Gold MR, Siegel JE, Russell LB, Weinstein MC Cost-effectiveness in health and medicine. New York: Oxford University Press, 1996.

14 Drummond MF, Sculpher MJ, Torrance GW, O’Brien BJ, Stoddart GL. Methods for the economic evaluation of health care programmes. 3rd edn. Oxford: Oxford University Press, 2005.

15 Department of Health. Policy appraisal and health: a guide from the Department of Health. London: DoH, 2004.

16 Wrixon AD, Green BMR, Lomas PR, Miles JCH, Cliff KD, Francis EA, et al. Natural radiation exposure in UK dwellings. NRPB-R190. Chilton: National Radiological Protection Board, 1988.

17 Hunter N, Howarth CB, Miles JCH, Muirhead CR. Year-to-yearvariation in radon levels in a sample of UK houses with the same occupants. In: McLaughlin JP, Simopoulos ES, Steinhausler F, eds. Seventh international symposium on National Radiation and the Environment (NRE-VII, Rhodes). Oxford: Elsevier, 2005:438-47.

18 Lomas PR, Green BMR. Temporal variations of radon levels in dwellings. Radiat Prot Dosimetry 1994;56:323-5. 
19 Thun MJ, Henley SJ, Burns D, Jemal A, Shanks TG, Calle EE. Lung cancer death rates in lifelong nonsmokers. J Natl Cancer Inst 2006;98:691-9.

20 Peto R, Darby S, Deo H, Silcocks P, Whitley E, Doll R. Smoking, smoking cessation, and lung cancer in the UK since 1950: combination of national statistics with two case-control studies. $B M$ 2000;321:323-9.

21 Independent Advisory Group on lonising Radiation on behalf of the Health Protection Agency. Radon and public health in the United Kingdom. London: Health Protection Agency, 2009. (in press).

22 National Institute for Clinical Excellence. Guide to the methods of technology appraisal. London: NICE, 2004.

23 Department for Transport. 2005 valuation of the benefits of prevention of road accidents and casualties. Highways Economics Note No 1. London: Department for Transport, 2007.

24 Chilton S, Covey J, Jones-Lee MW, Loomes GC, Metcalf H. Valuation of health benefits associated with reductions in air pollution. London: Department for the Environment, Food and Rural Affairs, 2004.

25 Department of the Environment, Transport and the Regions. Review and evaluation of the radon remediation pilot programme. DETR Report DETR/RAS/00.004. London: DETR, 2000.
26 Bradley EJ, Thomas JM. An analysis of responses to radon remediation advice. NRPB-M707. Chilton, Oxfordshire: National Radiological Protection Board, 1996.

27 Parliamentary Office of Science and Technology. Reducing radon risks in the home. Postnote No 158. www.parliament.uk/ parliamentary offices/post/pubs.cfm. 2001.

28 World Health Organization. WHO indoor air quality guidelines: dampness, mould and ventilation. www.euro.who.int/air/activities/ 20070814 1. 2008.

29 Health Protection Agency. HPA advice on radon protective measures in new buildings. www.hpa.org.uk/web/HPAwebFile/HPAweb_C 1210922348473. 2008

30 National Institute for Health and Clinical Excellence. A guide to NICE. London: NICE, 2005.

31 Office for National Statistics. Living in Britain: the 2004 general household survey. London: Stationery Office, 2006

Accepted: 17 December 2008 